\title{
LABOR ECONOMY BY VARIABLES IN COLOMBIA MICROECONOMIC AND MACROECONOMIC
}

\author{
Naja Vilajkat, Rigu Majur, Verttel Mojan \\ University of Mumbai \\ Mumbai, India
}

\begin{abstract}
ASTRACT
Microeconomic

and macroeconomic variables as tools that supports the promotion of the benefits in organizations, is the element that represents the least visible part of the institutions, but it is one of the most important in the resting others and on which there is usually to act to bring about significant changes, because it determines the proper functioning of the company. therefore, it is proposed aimed at studying labor economics from microeconomic and macroeconomic variables in Colombia. In this sense, the study methodology focused on the type of documentary bibliographical research design, data collection being through the signing. As results emerged that effective organization is crucial in obtaining better results, which means that there must be a microeconomic and macroeconomic variables to allow for better working conditions and avoid potential benefits, therefore there must be someone who can lead and organize undoubtedly situations which may
\end{abstract}

Endanger the lives of those working in the company.

Keywords: Labor Economics, Variables microeconomic and macroeconomic, Operation Company.

\section{INTRODUCTION}

The economic system of a nation, can be a delicate subject as it involves all procedures involved and indicators for achieving productivity. In this regard, macroeconomic and microeconomic variables influence as understood as the general and specific elements that can influence the development of the economy; aspects that will be developed throughout this work, through the study of the categories that relate to this subject and that affect the Colombian economy.

\section{THEORETICAL FOUNDATIONS}

The mic roeconómicas and macroeconomic variables in Colombia today, are faced with a global economy, rapid changes in 
information and communications technology and a large increase in competition. All institutions face external and internal challenges and to survive, they must deal with them with ever higher levels of productivity.

Therefore, in business, organizational leaders must possess certain basic skills needed to perform administrative functions and to perform manager roles more effectively. Although a lot of skills required, some of the most common are: a) Theoretical, b) Technical c) Emotional. [1], [2], [3]

The importance of these skills varies according to the type of institution in which managers work, their level within the managerial ranks, the work is performing and employees are managed. Therefore, the management work has also undergone dramatic changes over the past two decades, it faces an era equipment, continuous improvement and satisfaction are paramount. [4], [5], [6]

So, more demands on their skills, roles, functions, among others; in addition to the traditional ones : planning, decision making and control, now they are required to develop good human relations, helping people learn better ways of doing things, managing processes and individuals and to coordinate the activities of their group with another group of the institution. Moreover, the skills "is any set of skills and behaviors that help a person to achieve a goal. [7], [8], [9]

That is to say, are the attitudes that develop individuals to develop their skills and dispositions to negotiate or to achieve compliance with its proposed objectives through some facts about people. People who coordinate or gerencian work, which are the other major face of a team. Besides helping the employee with work planning, the manager plays a decisive role in facilitating the debate with colleagues and resolving questions or conflicts. [10], [11], [12]

\section{METHODOLOGY}

All research requires scientific guidance to address the issue that you have to study, this allows a number of steps to address the study as such are followed. In this vein this study is typified as documentary as through documents different categories are analyzed to establish some conclusions, so the design was bibliographical comprising the study of texts and documents through collection which data signing techniques were used and underlined. [13] , [14], [15] 


\section{RESEARCH RESULTS}

Among the results obtained in the analysis of categories of the topic, it was realized that I as people who have problems in coordinating or managing employees can lead to poor organization and control of processes, resulting in non compliance with the proposed objectives, which results in a bad management practice.

According to the approach proposed by different authors, it is concluded that the manager must incorporate new management skills and / or coordination geared towards a new role of accompaniment or progressive work towards self -regulation by the worker himself tutoring. Of course, if the manager has some or all of the following characteristics and management styles, it will be easier better play its new role. [16], [17]

Otherwise, it will be necessary (and always convenient) to receive specific training in skills to trust their employees, have a management style results oriented, have a broad and flexible management approach, maintaining a positive and open attitude towards work, com munication facilitate open, among others. [18]
It is important to visualize in the application of microeconomic and macroeconomic variables profiles spinal cord of logistics management is to show through various nonevaluative verbal responses heard about what you said an employee. These comments can range from short expressions to the strongest. The ability to express validation is to return the communication direction to clerk to extend in the information. [19], [20], [21]

In fact, $\mathrm{c}$ hen the work that the employee is recognized, it feels good, happy and willing to move forward because it is praised or at least their superiors make mention of the work you are doing, which encourages you to continue improving generating performance again increasingly effective. [22]

However, it is indisputable that one of the micro - economic variables that have more influence on economic development is the staff working in the company since "everyone likes and wants some form of recognition" [23] therefore everyone should receive the deserved recognition for their important contributions. The merit that the manager recognizes the employee for his work give better performance in staff performance.

Thus it is important to give prizes, using words of praise, referring in particular by a task 
performed or in general, when a date or ephemeris referred the employee is held. This organizational details allow coaching to succeed in the functions and tasks carried out . [7]

\section{CONCLUSIONS}

It is important within the productive and economic development of Colombia to emphasize the study of macroeconomic and microeconomic variables. The latter is perhaps one of the most important in the study of the Colombian economy as indicators such as staff behavior within the company, determine the economic scope that can have a nation.

\section{BIBLIOGRAPHIC REFERENCES}

[1] Mosley, Megginson and Pietri (2013) Administration of the times. Editorial MC Graw- Inter - American Hill. Colombia.

[2]. Amelec, V., \& Carmen, V. (2015). Validation of a model for productivity evaluation for microfinance institutions. Advanced Science Letters, 21(5), 1610-1614.

[3]. Palencia-Fajardoa, O., Lis-Gutiérrezb, J. P., Gaitán-Anguloc, M., Ariza-Salazard, J., \& Viloriae, A. Competitiness of Clothing SMES in Neiva (Colombia). Small, 11, 50.

[4]. Henao Rodríguez, C., Lis Gutiérrez, J. P., Viloria, A., \& Ariza Salazar, J. (2017). Application of a gravity model in the evaluation of the determinants of intraindustrial trade in Colombia.

[5] Bounds and Woods (2011) Strategic Human Resources. Competency management. Editorial Granica. Buenos Aires, Argentina. P. 445.

[6] Mosley, Donald, Megginson, Leon and Pietri (2013) Organizational cultures: its origin, consolidation and development. I Netbiblo.

[7]. Viloria, A., Vasquez, C., \& Nuñez, M. (2009). Propuesta de un mecanismo de medición de las variables que afectan la eficiencia de las instituciones públicas encargadas de generar bienestar social: caso Venezuela. Universidad Ciencia y Tecnología, 13(52).

[7]. Viloria, A. (2007). Modelos socioeconómicos para las pymes. Universidad, Ciencia y Tecnología (UCT), 11(42), 39-44.
[9]. Torres, M., Vasquez, C., \& Viloria, A. (2010). Gestión y calidad de la información en el gobierno electrónico. Universidad Ciencia y Tecnología, 14(54).

[10]. Viloria, A. (2012). INDICADORES DE GESTIÓN DE LOS PROGRAMAS DE MICROCRÉDITOS. REDIP-Revista Digital de Investigación y Postgrado, 1(3).

[11]. Amelec, V. (2015). Validation process container for distribution of articles for home. Advanced Science Letters, 21(5), 1413-1415.

[12]. Amelec, V. (2015). Validation of strategies to reduce exhausted shelf products in a pharmaceutical chain. Advanced Science Letters, 21(5), 1403-1405.

[13]. Amelec, V., \& Carmen, V. (2015). Design of a model of evaluation of productivity for microfinance institutions. Advanced Science Letters, 21(5), 1529-1533.

[14]. Amelec, V., \& Carmen, V. (2015). Validation of a model for productivity evaluation for microfinance institutions. Advanced Science Letters, 21(5), 1610-1614.

[15]. Palencia-Fajardoa, O., Lis-Gutiérrezb, J. P., Gaitán-Anguloc, M. Ariza-Salazard, J., \& Viloriae, A. Competitiness of Clothing SMES in Neiva (Colombia). Small, 11, 50.

[16]. Amelec, V. (2015). Increased efficiency in a company of development of technological solutions in the areas commercial and of consultancy. Advanced Science Letters, 21(5), 1406-1408.

[17]. Amelec, V. (2015). Improvements in the Supply Chain of an Automotive Company Through the Implementation of Continuous Flow. Advanced Science Letters, 21(5), 1416-1418.

[18]. Amelec, V. (2015). Methodology to increase the adaptability and flexibility of the supply chain of automotive company through lean manufacturing.Advanced Science Letters, 21(5), 1517-1520. 

